Journal An-Nafs: Kajian Penelitian Psikologi

http://ejournal.iai-tribakti.ac.id/index.php/psikologi

e-ISSN: 2549-6166

p-ISSN: 2528-0600

\title{
DINAMIKA KEPRIBADIAN NARAPIDANA KASUS PEMBUNUHAN DENGAN GANGGUAN KEPRIBADIAN ANTISOSIAL
}

\author{
Nanda Audia Vrisaba ${ }^{1}$ \& Ktut Dianovinina ${ }^{2}$ \\ 15120087.nanda@gmail.com, 2kdianovinina@gmail.com \\ Universitas Surabaya \\ https://doi.org/10.33367/psi.v4i2.827
}

\begin{abstract}
Abstrak
Gangguan kepribadian antisosial yang dialami oleh seseorang menyebabkan mereka melakukan tindakan yang menyimpang dan melanggar norma maupun nilai yang berlaku disekitarnya, sehingga tak banyak dari mereka merupakan narapidana yang mendekam di dalam tahanan. Penelitian ini bertujuan untuk mengetahui dinamika keperibadian yang dimiliki oleh narapidana yang mengalami gangguan kepribadian antisosial. Peneliti juga akan mengidentifikasi beberapa penyebab yang membentuk seseorang mengalami gangguan kepribadian antisosial. Peneliti menggunakan metode studi kasus dengan pendekatan secara kualitatif. Partisipan pada penelitian ini berjumlah satu orang, yaitu Mahmud narapidana kasus pembunuhan berencana dan kasus percobaan penculikan anak di bawah umur. Pada proses pemeriksaan, peneliti menggunakan observasi, wawancara, dan beberapa tes psikologi lainnya. Hasil menunjukkan bahwa gangguan kepribadian antisosial yang dialami oleh partisipan tidak serta merta terbentuk saat dewasa, namun sejak masa kanakkanak partisipan telah menunjukkan beberapa perilaku yang menyimpang. Selain itu, faktor ektsternal juga memiliki pengaruh dalam membentuk seseorang memiliki gangguan kepribadian antisosial.
\end{abstract}

Kata Kunci: Gangguan kepribadian, antisosial, narapidana 


\begin{abstract}
Antosocial personality disorder experienced by someone caused them to take deviant actions and violate the norms and values of their surrounding, so that many of them are prisoners who are in custody. This study aims to determine the personality dynamics possessed by prisoner who experienced antisocial personality disorders. The researcher will also identify several causes that make up a person experiencing an antisocial personality disorder. The researcher used a case study method with a qualitative approach. There is one participant in this study, namely Mahmud, an prisoner of a homicide and involved in an abductions case. During the research process, researcher used observation, interviews, and several psychological tests. The finding shows that antisocial personality disorders experienced by participants was not formed when he was in the adult period, but since his childhood some deviant behavior were indicated. In addition, external factors also have influence in forming a person who has an antisocial personality disorder.
\end{abstract}

Keyword: Personality disorder, antisocial, prisoner

\title{
Pendahuluan
}

Lembaga pemasyarakatan (Lapas) atau yang seringkali disebut sebagai tahanan merupakan tempat berkumpulnya berbagai orang yang melakukan tindakan melanggar hukum, norma, maupun nilai yang berlaku di masyarakat. Penyimpangan tindakan yang dilakukan contohnya melakukan pembunuhan, pelecehan seksual, tindakan korupsi, hingga penggunaan obatobatan terlarang. Mendekamnya narapidana di tahanan merupakan bentuk hukuman dan diyakini agar mereka yang melakukan pelanggaran tersebut dapat menyadari kesalahannya dan berusaha untuk tidak mengulangi tindakan tersebut lagi. Lamanya hukuman yang diberikan bergantung pada tindakan yang dilakukan dan disesuaikan dengan hukum yang berlaku.

Tak banyak juga seseorang yang pernah mendekam dalam sel tahanan tidak merasa kapok dan tidak merasa bersalah akan tindakannya, sehingga mereka melakukan tindakan melanggar lainnya. Hal ini merupakan salah satu karakteristik orang dengan gangguan kepribadian antisosial. Individu dengan gangguan 
kepribadian antisosial seringkali melakukan pelanggaran norma, kurangnya rasa bersalah, sulitnya mempertahankan suatu hubungan, mudah untuk memanipulasi situasi atau keadaan, hingga mengabaikan hak orang lain (deFarias,et.al, 2013). Hal ini mereka lakukan semata-mata untuk mendapatkan keuntungan pribadi.

Sedangkan Maramis (1980) menjelaskan bahwa kepribadian antisosial itu ditandai dengan adanya perilaku berulang yang membawanya ke dalam konflik dengan masyarakat. Subjek tidak memiliki loyalitas dengan kelompoknya ataupun norma sosial yang ada, pada umumnya egosentrik, tidak bertanggungjawab, impulsif, tidak mampu mengubah diri, baik karena faktor pengalaman atau hukuman yang ia dapatkan. Memiliki tingkat kekecewaan yang rendah, sehingga ia cenderung untuk menyalahkan orang lain akan perilaku yang ia perbuat.

Individu dengan gangguan kepribadian antisosial menunjukkan gejala yang muncul sejak mereka kecil. Orang dewasa dengan kepribadian antisosial ditemukan adanya kenakalan (conduct disorder atau CD) yang dilakukan pada masa remaja, seperti mencuri, lari dari rumah, membolos dan lainnya (Maramis, 1980). Perilaku antisosial yang dilakukan pada anakanak pada mulanya di diagnosis sebagai oppositional defiant disorder (ODD), dimana ditandai dengan adanya perilaku yang terus-menerus bermusuhan, menantang, menganggu, dan toleransi frustasi yang rendah (Glenn \& Raine, 2011). Hal ini menunjukkan bahwa kepribadian antisosial tidak serta merta langsung muncul pada diri seseorang, namun adanya perkembangan dari masa kanak-kanak (ODD), remaja (CD), hingga dewasa menjadi antisosial.

Sama halnya dengan gangguan mental lainnya, terbentuknya gangguan kepribadian antisosial juga merupakan pengaruh dari faktor biologis atau bawaan dan faktor psikososial (NICE Clinical Guidelines, 2010). Faktor biologis dari individu dengan gangguan kepribadian antisosial ditandai dengan perilaku agresif yang dilakukan, sedangkan faktor psikososial yang turut 
berperan adalah adanya pola asuh yang tidak konsisten yang diterapkan dalam keluarganya (NICE Clinical Guidelines, 2010).

Berdasarkan penjelasan diatas, peneliti tertarik untuk ingin mengetahui dinamika kepribadian dari narapidana dengan gangguan kepribadian antisosial. Peneliti ingin memaparkan faktor-faktor penyebab yang turut berperan dalam terbentuknya gangguan kepribadian antisosial.

Ciri utama atau penting dari antisocial personality disorder adanya pengabaian dan pelanggaran yang dilakukan awal remaja hingga berlanjut sampai dewasa. Pola ini disebut dengan sebagai psikopat, sosiopat, atau dyssocial personality disorder. Penipuan dan manipulatif sangat merupakan inti dari gangguan kepribadian ini. Menurut DSM - V (APA, 2013) menjelaskan kriteria diagnostik untuk antisocial personality disorder, dimana gangguan ini masuk dalam kategori personality disorder pada cluster 1. Kriteria kriteria tersebut diantaranya:

a. Adanya pola pengabaian dan pelanggaran terhadap hak orang lain, terjadi sejak usia 15 tahun, dimana ditandai dengan setidaknya tiga atau lebih kriteria dibawah ini:

1. Kegagalan menyesuaikan diri dengan norma-norma sosial maupun hukum. Berulang kali melakukan tindakantindakan yang bisa menjadi dasar penangkapan kepadanya. Seperti melakukan pekerjaan ilegal, mencuri, atau melecehkan orang lain.

2. Melakukan penipuan, dimana ditandai dengan melakukan pem-bohongan berulang kali, menggunakan nama palsu, atau menipu orang lain untuk keuntungan dirinya sendiri.

3. Adanya pola impulsivitas dan kegagalan dalam melakukan perencanaan ke depan. Orang akan selalu melakukan keputusan yang serba mendadak, bertindak tanpa berpikir, tidak memikirkan konsekuensi maupun resiko yang akan ia atau orang lain peroleh.

4. Irritability dan agresif, dimana ditandai dengan berulangkali melakukan atau terlibat dalam perkelahian secara fisik. 
Nanda Audia Vrisaba \& Ktut Dianovinina | Dinamika Narapidana

5. Mengabaikan atau sembrono untuk keselamatan diri sendiri maupun orang lain. Contoh perilaku seperti mengemudi sambil mabuk, mengkonsumsi zat yang memiliki resiko tinggi, hingga terlibat hubungan seksual yang beresiko juga.

6. Tidak memiliki tanggung jawab secara konsisten. Seperti lama menganggur meskipun ada peluang pekerjaan atau meninggalkan pekerjaan tanpa adanya rencana untuk mendapatkan pekerjaan lain. Kegagalan dalam pengaturan keuangan, sehingga mengakibatkan tidak bisa untuk membayar kewajiban atau tunjangan untuk keluarga.

7. Kurang adanya rasa penyesalan dalam diri. Ia akan cenderung membela diri, menyalahkan korban, atau ia mampu untuk meminimalkan hukuman terkait tindakan mereka.

b. Individu setidaknya berusia minimal 18 tahun.

c. Adanya bukti conduct disorder yang dilakukannya pada onset 15 tahun. Conduct disorder merupakan pola perilaku berulang atau terus-menerus dilakukan yang melanggar norma atau aturan masyarakat.

d. Tidak termasuk dalam schizophrenia atau bipolar disorder.

\section{Metode Penelitian}

Pemilihan partisipan yang dilakukan peneliti menggunakan metode purposive sampling, dimana pemilihan partisipan berdasarka kriteria-kriteria yang ditentukan (Sugiyono, 1999). Kriteria partisipan yang dipilih merupakan narapidana yang sebelumnya telah terdiagnosa antisocial personality disorder dan yang bersedia untuk menjadi partisipan penelitian. Partisipan pada penelitian kali ini berjumlah satu orang yang bernama Mahmud. Mahmud merupakan narapidana dengan dua pasal berlapis, yaitu kasus pembunuhan berencana (pasal 340 ayat 2) dengan hukuman 20 tahun penjara dan kasus percobaan penculikan anak usia dini (pasal 58 ayat 1 ) dengan hukuman 3 tahun penjara. Mahmud telah

134 | Journal An-nafs: Vol. 4 No. 2 Desember 2019 
Nanda Audia Vrisaba \& Ktut Dianovinina | Dinamika Narapidana mendekam di tahanan sejak tahun 2009. Berikut akan disajikan identitas dari partisipan:

Tabel 1.

Tabel Identitas Partisipan

\begin{tabular}{|l|r|l|}
\hline Nama & $:$ & Mahmud (Nama Samaran) \\
\hline Jenis Kelamin & $:$ & Laki-laki \\
\hline Tempat, Tanggal Lahir & $:$ & Tuban, 2 Maret 1989 \\
\hline Usia & $:$ & 29 Tahun 1 Bulan \\
\hline Alamat & $:$ & Jayapura, Papua \\
\hline Pendidikan Terakhir & $:$ & SMA \\
\hline Pekerjaan & $:$ & Pengerajin Gypsum (Sebelum Kasus) \\
\hline Suku Bangsa & $:$ & Jawa \\
\hline Latar Belakang Budaya & $:$ & Jawa Timur \\
\hline Agama & $:$ & Islam \\
\hline Urutan Kelahiran & $:$ & 1 dari 3 Bersaudara \\
\hline
\end{tabular}

Pada penelitian ini, peneliti akan menggunakan beberapa metode dalam melakukan analisis data. Metode yang digunakan diantaranya, 1) observasi untuk mengetahui gambaran perilaku yang ditunjukkan oleh partisipan selama berhadapan dengan peneliti; 2) wawancara digunakan untuk menggali informasinformasi yang meliputi riwayat kehidupan semasa kecil hingga saat ini, kronologis tindakan kriminal yang dilakukan, hingga relasi sosial yang dimiliki partisipan; 3) tes psikologi yang meliputi tes grafis, Weschler Bellevue Intelligence test, Hare Psychophaty Inventory, Minnesota Multiphasic Personality Inventory (MMPI), Thematic Apperception Test (TAT), dan checklist antisocial personality disorder berdasarkan DSM-V (2013). Beberapa alat tes tersebut digunakan untuk memberikan informasi gambaran kepribadian dan permasalahan yang dimiliki oleh partisipan; 4) dokumen atau arsip yang berkaitan, seperti dokumen putusan persidangan untuk membantu mengetahui kronologis kerjadian perkara dan disesuaikan dengan hasil wawancara yang dikemukakan partisipan. 
Nanda Audia Vrisaba \& Ktut Dianovinina | Dinamika Narapidana

\section{Paparan Hasil}

Berdasarkan hasil pemeriksaan bahwa partisipan memenuhi keseluruhan kriteria dari gangguan kepribadian antisosial berdasarkan DSM-V (2013). Berikut akan disajikan tabel diagnosa hasil pemeriksaan yang dilakukan kepada partisipan berdasarkan DSM-V:

Tabel 2.

Tabel Diganosa Hasil Pemeriksaan Mahmud menurut DSM-V

\begin{tabular}{|c|c|c|c|}
\hline Kriteria & $\sqrt{ }$ & Bentuk Perilaku & Sumber Data \\
\hline \multicolumn{4}{|c|}{$\begin{array}{l}\text { A. Pola yang berkaitan adanya pengabaian dan pelanggaran hak orang } \\
\text { lain yang terjadi sejak usia } 15 \text { tahun, minimal ditunjukkan dengan } 3 \\
\text { kriteria. Diantaranya : }\end{array}$} \\
\hline $\begin{array}{l}\text { 1. Kegagalan } \\
\text { menyesuaikan diri } \\
\text { terhadap norma- } \\
\text { norma sosial dengan } \\
\text { hukum. }\end{array}$ & $\sqrt{ }$ & $\begin{array}{l}\text { ○ Melakukan tindak } \\
\text { pidana. } \\
\text { O Berkali-kali } \\
\text { berhubungan seksual } \\
\text { dengan pacarnya. } \\
\text { - Sering menyalahgunakan } \\
\text { ganja dan inex. }\end{array}$ & $\begin{array}{l}\text { o Wawancara } \\
\circ \text { Hare } \\
\circ \text { WB } \\
\circ \text { MMPI }\end{array}$ \\
\hline 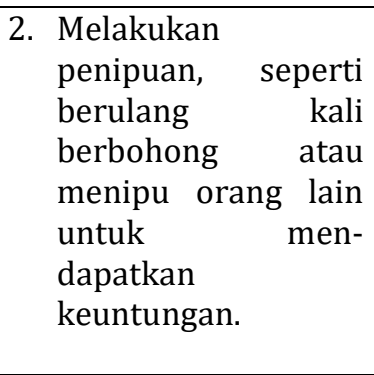 & $\sqrt{ }$ & $\begin{array}{l}\text { o Melakukan penipuan } \\
\text { untuk mendapatkan } \\
\text { keuntungan } \rightarrow \text { berkaitan } \\
\text { dengan uang. } \\
\text { o Memanipulasi keadaan } \\
\text { untuk mendapatkan yang } \\
\text { diinginkan. } \\
\text { O Cerita tidak sesuai } \\
\text { dengan surat putusan. }\end{array}$ & $\begin{array}{l}\text { ○ Wawancara } \\
\circ \text { Hare } \\
\circ \text { MMPI } \\
\circ \text { Dokumen } \\
\quad \text { putusan }\end{array}$ \\
\hline $\begin{array}{l}\text { 3. Impulsif atau } \\
\text { kegagalan dalam } \\
\text { perencanaan / tidak } \\
\text { memikirkan } \\
\text { konsekuensi. }\end{array}$ & $\sqrt{ }$ & $\begin{array}{lr}\text { Sering } & \text { bertindak } \\
\text { sebelum memikirkan } \\
\text { konsekuensi } \\
\text { diterima } \rightarrow \text { kabur dari } \\
\text { penjara dan tindakan } \\
\text { membunuh. } \\
\text { O Melakukan } \\
\text { kekerasan, tindak } \\
\text { memukul teman untuk } \\
\text { membela teman. }\end{array}$ & $\begin{array}{l}\text { ○ Wawancara } \\
\text { o Hare } \\
\text { o Grafis } \\
\text { o MMPI } \\
\circ \text { WB }\end{array}$ \\
\hline $\begin{array}{l}\text { 4. Mudah tersinggung } \\
\text { dan agresif, yang } \\
\text { ditunjukkan dengan } \\
\text { berulangkali me- } \\
\text { lakukan serangan }\end{array}$ & $\sqrt{ }$ & $\begin{array}{lr}\text { O Memiliki riwayat sering } \\
\text { melakukan } & \text { tindakan } \\
\text { yang } & \text { tergolong } \\
\text { kekerasan } & \text { fisik, sejak }\end{array}$ & $\begin{array}{l}\text { O Wawancara } \\
\text { o Grafis } \\
\circ \text { Hare } \\
\circ \text { MMPI }\end{array}$ \\
\hline
\end{tabular}

136 | Journal An-nafs: Vol. 4 No. 2 Desember 2019 
Nanda Audia Vrisaba \& Ktut Dianovinina | Dinamika Narapidana

\begin{tabular}{|c|c|c|c|}
\hline Kriteria & $\sqrt{ }$ & Bentuk Perilaku & Sumber Data \\
\hline $\begin{array}{l}\text { atau pertarungan } \\
\text { secara fisik. }\end{array}$ & & $\begin{array}{l}\text { duduk di bangku sekolah } \\
\text { hingga selama di penjara. } \\
\text { o Sensitif dan mudah } \\
\text { tersinggung dengan } \\
\text { omongan teman yang } \\
\text { mengatai dirinya. }\end{array}$ & \\
\hline 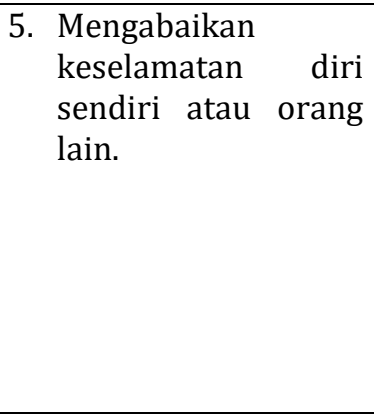 & $\sqrt{ }$ & $\begin{array}{l}\text { O Setiap memukul orang } \\
\text { tidak memikirkan } \\
\text { keselamatan orang lain. } \\
\text { o Sering terlibat hubungan } \\
\text { seksual dan } \\
\text { penyalahgunaan ganja } \\
\text { dan inex, serta alkohol } \\
\text { berkadar 40\% } \\
\text { Sering mengikuti road } \\
\text { race. }\end{array}$ & $\begin{array}{l}\text { ○ Wawancara } \\
\circ \text { Hare }\end{array}$ \\
\hline 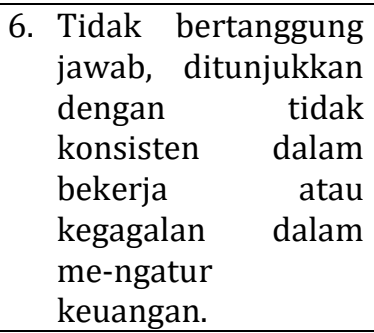 & $\sqrt{ }$ & $\begin{array}{l}\text { o Sering kesulitan dalam } \\
\text { mengatur keuangan, } \\
\text { cenderung boros. } \\
\text { o Tidak bertanggung jawab } \\
\text { akan kesalahannya, } \\
\text { sehingga melimpahkan } \\
\text { kesalahan pada orang } \\
\text { lain. }\end{array}$ & $\begin{array}{l}\text { o Wawancara } \\
\circ \text { Hare } \\
\circ \text { MMPI }\end{array}$ \\
\hline $\begin{array}{l}\text { 7. Kurangnya rasa } \\
\text { penyesal-an, seperti } \\
\text { sikap acuh tak acuh } \\
\text { setelah menyakiti } \\
\text { orang lain. }\end{array}$ & $\sqrt{ }$ & $\begin{array}{lr}\text { O Proses BAP } \rightarrow \\
\text { menganggap bahwa dia } \\
\text { benar karena haknya ada } \\
\text { di korban. } \\
\text { o Sering melakukan } \\
\text { kesalahan lagi, tidak } \\
\text { kapok untuk } \\
\text { mendapatkan hukuman } \\
\text { (kabur penjara 2x) } \\
\text { Teman di hukum } \\
\text { pukulan dan kurungan } \\
\text { sel gelap tidak merasa } \\
\text { bersalah dan tidak mau } \\
\text { mengakui kalau dia } \\
\text { pengedarnya. }\end{array}$ & $\begin{array}{l}\text { Wawancara } \\
\circ \text { Hare } \\
\circ \text { Dokumen } \\
\text { putusan }\end{array}$ \\
\hline $\begin{array}{lr}\text { B. } & \text { Individu berusia } \\
\text { setidaknya } & 18 \\
\text { tahun } & \\
\end{array}$ & $\sqrt{ }$ & $\begin{array}{l}\text { Saat ini usia subjek } 29 \\
\text { tahun, dimana mulai di } \\
\text { penjara sejak usia } 20 \text { tahun. }\end{array}$ & $\begin{array}{l}\text { O Wawancara } \\
\text { Dokumen } \\
\text { putusan }\end{array}$ \\
\hline $\begin{array}{l}\text { C. Adanya bukti ter- } \\
\text { jadinya conduct }\end{array}$ & $\sqrt{ }$ & $\begin{array}{l}\text { Adanya perilaku conduct } \\
\text { meliputi agresi, pencurian }\end{array}$ & $\begin{array}{l}\text { ○ Wawancara } \\
\text { ○ Hare }\end{array}$ \\
\hline
\end{tabular}


Nanda Audia Vrisaba \& Ktut Dianovinina | Dinamika Narapidana

\begin{tabular}{|l|l|l|l|}
\hline \multicolumn{1}{|c|}{ Kriteria } & $\sqrt{ }$ & \multicolumn{1}{|c|}{ Bentuk Perilaku } & Sumber Data \\
\hline $\begin{array}{l}\text { behavior di onset } \\
\text { sebelum usia 15 } \\
\text { tahun. }\end{array}$ & & $\begin{array}{l}\text { atau ketidak-jujuran, dan } \\
\text { pelanggaran aturan. }\end{array}$ & \\
\hline $\begin{array}{l}\text { D. } \\
\text { Tidak tergolong } \\
\text { dalam } \\
\text { schizophrenia } \\
\text { ataupun bipolar } \\
\text { disorder. }\end{array}$ & $\sqrt{ }$ & $\begin{array}{l}\text { Tidak ditemukan adanya } \\
\text { simptom positif maupum } \\
\text { nengatif terkait } \\
\text { schizophrenia pada subjek. } \\
\text { Serta tidak adanya } \\
\text { perubahan suasana hati } \\
\text { yang signifikan atau } \\
\text { ekstrem. }\end{array}$ & $\begin{array}{l}\text { ○ Observasi } \\
\circ \text { Grafis }\end{array}$ \\
\hline
\end{tabular}

Berdasarkan hasil pemeriksaan menunjukkan bahwa sejak kecil Mahmud nampak menunjukkan adanya perilaku yang berlawanan dengan yang ada di sekitarnya. Perilaku berlawanan ini mengarah kepada oppositional defiant disorder. Ia mudah untuk mengganggu hingga menyerang temannya maupun orang lain secara tiba-tiba, tanpa ada alasan atau tujuan yang jelas. Perilaku berlawanan ini diperkuat karena adanya pengalaman, dimana ibu Mahmud membelanya atas kesalahan yang diperbuat Mahmud dengan membalas pertengkaran dengan orang tua teman Mahmud. Perilaku berlawanan tersebut berkembang hingga ia tumbuh menjadi sosok remaja yang memiliki banyak riwayat perilaku conduct.

Beberapa perilaku yang sering Mahmud lakukan adalah adanya ketidakjujuran ataupun manipulatif untuk mendapatkan keuntungan bagi dirinya. Ia seringkali tidak jujur dalam hal pemakaian uang, hingga seringkali menipu ayahnya untuk mendapatkan sesuatu yang ia inginkan. Perilaku conduct lain adalah seringkali ia melanggar aturan yang ada di sekolah, di rumah, hingga pelanggaran akan norma dan nilai yang ada di lingkungan sekitarnya.

Dalam bertindak, Mahmud cenderung bertindak terlebih dahulu tanpa memikirkan resiko maupun konsekuensi yang nantinya akan terjadi pada dirinya. Mahmud baru dapat memikirkan resiko yang akan ia terima ketika ia telah melakukan tindakan tersebut. Sedangkan dalam penyelesaian masalah, 
Mahmud seringkali menyelesaikan masalah dengan menggunakan coping yang tidak tepat. Ia lebih menggunakan kekerasan atau agresi untuk dapat menyelesaikan suatu permasalahan, dimana dari salah satu bentuk agresi yang ia lakukan membuatnya terkena tindak pidana.

Perilaku yang sering melanggar aturan atau norma yang ada berkembang menjadi adanya kecenderungan Mahmud memiliki pribadi yang antisosial. Penipuan, sering terlibat serangan fisik, perilaku yang mengabaikan keselamatan diri, tidak memiliki rasa tanggung jawab, hingga rasa bersalah telah dimiliki oleh Mahmud. Kepribadian antisosial yang dimilikinya saat ini merupakan perkembangan dari adanya kecenderungan ODD saat kecil dan perilaku conduct yang ia lakukan saat remaja.

Terdapat dua faktor yang membuat Mahmud mengembangkan pribadi antisososial, faktor eksternal dan faktor internal. Faktor eksternal yang sangat berpengaruh adalah adanya kecenderungan ambivalensi pola asuh orang tua antara ayah dan ibu. Ayah lebih menerapkan pola asuh yang memanjakan atau permissive, dimana menurut Carr (2006) anak yang mendapatkan pola pengasuhan permissive akan mengembangkan menjadi pribadi yang memiliki kontrol diri yang kurang baik. Adanya kontrol diri yang kurang baik ini merupakan salah satu faktor internal yang membentuk Mahmud memiliki kecenderungan kepribadian antisosial.

Berbeda dengan ayah, ibu Mahmud lebih menerapkan pola asuh yang tidak konsisten. Ibu sering kali memberikan punishment dalam bentuk pukulan atau agresi, namun terkadang tidak memberikan konsekuensi apapun akan tindakan dari Mahmud. Selain ibu, Mahmud juga mendapatkan agresi fisik yang diberikan oleh kakek dan guru di sekolahnya. Carr (2006) menjelaskan bahwa adanya punishment dalam bentuk agresi akan membuat anak belajar bahwa cara menyelesaikan suatu permasalahan adalah dengan menggunakan agresi, dimana anak yang sering mendapatkan agresi akan mudah untuk terlibat dalam perilaku conduct. 
Nanda Audia Vrisaba \& Ktut Dianovinina | Dinamika Narapidana

Selain itu, faktor eksternal yang juga mempengaruhi adalah seringkali ia melihat orang terdekatnya melakukan agresi. Seperti contohnya adalah Mahmud melihat langsung pukulan yang diberikan oleh ayah kepada ibunya. Adanya modelling ini serupa dengan apa yang dikemukakan oleh Bandura (1986, dalam Feist \& Feist, 2014) bahwa perilaku agresif yang dilakukan seseorang didapatkan melalui observasi dari orang lain. Bandura (1986) juga menjelaskan bahwa tindakan agresif dapat berakibat pada agresivitas yang berlanjut (dalam Feist \& Feist, 2014), mengingat Mahmud telah mendapatkan bentuk perilaku agresif sejak ia kecil.

\section{Pembahasan}

Permasalahan yang dihadapi partisipan saat ini adalah kasus kriminal yang telah dilakukan dan gangguan kepribadian antisosial yang dimilikinya. Gangguan kepribadian antisosial yang dimiliki partisipan cenderung mengarah pada kategori yang cukup berat. Moffitt, dkk (2008) mengungkapkan bahwa usia onset munculnya gangguan perilaku merupakan indikator kuat dari tingkat keparahan kepribadian antisosial yang dialami oleh individu dewasa (Walters \& Knight, 2010).

Gangguan kepribadian antisosial partisipan ditunjukkan dari adanya trait-trait yang dimiliki partisipan. Trait-trait tersebut dihasilkan dari pembentukan perkembangan kepribadiannya sejak kecil hingga saat ini. Salah satu yang berperan dalam pembentukan kepribadian dan proses berpikir individu adalah pihak keluarga atau pengasuhan yang terapkan orang tua kepada anak (Fernandes, 2019). Orang tua memiliki tugas penting untuk belajar menenangkan diri ketika stres atau marah dan membentuk hubungan yang sehat dengan anak (Adshead, 2015).

Ellis (2008) mengemukakan bahwa terdapat beberapa situasi yang dapat 'merusak' perkembangan anak, bahkan anak yang paling tangguh sekalipun. Situasi tersebut diantaranya kekerasan yang dilakukan orang tua, penolakan, ataupun perilaku yang nampak negatif yang dilakukan oleh orang tua (Adshead, 2015). Hal ini sesuai dengan berdasarkan pola asuh yang

140 | Journal An-nafs: Vol. 4 No. 2 Desember 2019 
didapatkan partisipan sejak dini, sehingga menjadi salah satu faktor resiko yang membentuk kepribadian antisosialnya. Partisipan sering berhadapan dengan situasi kekerasan yang dilakukan oleh orang sekitarnya, khususnya ibunya. Ibu seringkali membetikan hukuman fisik setiap kali partisipan melakukan suatu kesalahan. Selain itu, partisipan juga seringkali melihat ayahnya nampak memukul ibunya.

Situasi yang membuat partisipan merasa dekat dengan tindakan kekerasan menunjukkan bahwa orang tua tidak memiliki kemampuan yang tepat untuk merespon suatu tekanan. Oleh karena itu, hal ini berdampak pada perkembangan perilaku partisipan sejak dini (Adshead, 2015). Carr (2006) menjelaskan bahwa anak dengan pola asuh dengan diberikan suatu punishment akan membuat anak mengembangkan sikap agresi dalam memandang untuk penyelesaian masalah. Hal ini serupa dengan partisipan yang memiliki kecenderungan untuk melakukan perilaku agresif. Hal ini membuat partisipan mudah bertindak impulsif dengan kekerasan dalam situasi yang memancing amarahnya, seperti kebutuhan finansial yang kurang. Keadaan perkenomian yang rendah dengan adanya perilaku conduct yang dilakukan dapat menjadi prediktor berkembangnya kepribadian antisosial (Lahey, Burke, \& Applegate, 2005).

Partisipan menunjukkan sikap yang berlawanan sejak dirinya kecil dan berkembang menjadi suatu tindakan conduct semasa dirinya remaja. Washbrun, dkk (2007) mengungkapkan bahwa antisocial personality disorder berhubungan erat dengan conduct disorder yang dilakukan semasa individu remaja. Sebagian besar individu dengan kepribadian antisosial ditemukan adanya riwayat conduct yang dilakukan. Hal ini serupa dengan riwayat kenakalan remaja yang pernah dilakukan oleh partisipan.

Tufts (2013) merangkum beberapa faktor eksternal yang merupakan faktor resiko berkembangnya kepribadian antisosial, salah satunya adalah antisocial peer-group individu (dalam Lewis \& Clark Law, 2013). Selama ini, peran keluarga kurang mampu untuk memenuhi kebutuhan afeksi dari partisipan, sehingga 
Nanda Audia Vrisaba \& Ktut Dianovinina | Dinamika Narapidana

membuat partisipan berusaha mencari kebutuhan afeksi tersebut kepada teman-teman atau peer group-nya. Peer-group partisipan memiliki peran dalam mengajarkan partisipan untuk membolos, bermain balap motor, seks bebas, hingga minum-minuman keras dan terjerumus dalam obat-obatan yang terlarang. Hal ini mengembangkan perilaku partisipan mengarah pada kepribadian antisosial dan lebih berani untuk melakukan tindakan yang beresiko.

Kondisi kepribadian antisosial yang dimiliki partisipan tetap bertahan. Hal ini dikarenakan adanya kondisi yang mempertahankan atau kondisi yang membuat trait-trait subjek berkembang menjadi lebih buruk. Kondisi tersebut diantaranya adalah sebagian besar didapatkan subjek selama 8 tahun lebih di dalam tahanan. Selama di tahanan, berkembangnya kemampuan partisipan dalam hal kemampuan belajar dengan narapidana lainnya untuk melakukan hal-hal yang menguntungkan dirinya dan bersifat negatif. Contoh dari kemampuan partisipan tersebut adalah partisipan memiliki berbagai strategi untuk menyembunyikan sesuatu benda di suatu tempat yang tidak pernah terpikirkan dan memiliki berbagai cara untuk bisa kabur dari tahanan.

Selain itu, kepribadian antisosial memiliki hubungan yang erat dengan substance abuse (Fernandes, 2019). Bahkan, Loeber (2002) menemukan bahwa adanya hubungan yang lebih kuat antara penggunaan marijuana atau ganja oleh individu terhadap perkembangan kepribadian antisosial dibandingkan perilaku conduct (Washburn, dkk, 2007). Hal ini serupa dengan keadaan partisipan yang telah mengkonsumsi ganja lebih dari 10 tahun lamanya, bahkan ketika dirinya berada dalam penjara.

Kondisi lainnya adalah masih belum ada sosok pemenuh kebutuhan afeksi partisipan yang memiliki otorita yang lebih tinggi daripada dirinya. Hal ini membuat partisipan kurang memiliki seseorang yang mampu mengontrol dirinya, sehingga membuat kepribadian yang dimilikinya semakin berat. Kondisi keluarga saat ini juga belum dapat untuk dijadikan sebagai faktor pelindung

142 | Journal An-nafs: Vol. 4 No. 2 Desember 2019 
untuk memenuhi kebutuhan afeksi subjek tersebut. Ibu masih sering melakukan tindakan agresi dan ayah juga masih sering untuk menuruti apa yang diinginkan partisipan.

Berdasarkan pemaparan diatas menunjukkan bahwa sebagian besar faktor yang mempengaruhi kepribadian antisosial yang dimiliki partisipan adalah dari eksternal. Peneliti kurang menemukan adanya faktor internal atau biologis dalam diri partisipan yang ikut memberikan sumbangsih dalam pembentukan kepribadian tersebut. Sebuah studi yang dilakukan oleh King's College (2012) menemukan bahwa adanya kelainan spesifik pada struktur otak yang mengatur empati dan rasa bersalah sudah cukup untuk membedakan antara individu yang normal dengan yang psikopat (Fernandes, 2019).

Adanya kelainan pada salah satu struktur otak tersebut sejalan dengan salah satu karakteristik yang ditemui oleh individu dengan kepribadian antisosial. Individu dengan kepribadian antisosial akan cenderung mengembangkan rasa yang tidak mudah bersalah ketika melakukan suatu tindakan yang salah dan kurangnya rasa empati yang dimiliki terhadap orang lain (Black, 2015). 


\begin{tabular}{|ll|}
\hline \multicolumn{1}{|c|}{ Predisposing Factors } \\
1. & Kontrol norma yang rendah \\
2. & Perilaku pasif-agresif dalam menyelesaikan \\
& permasalahan. \\
3. & Menunjukkan kecenderungan sikap agresi. \\
4. & Kurang memiliki rasa bersalah atas tindakan \\
5. & yang dilakukannya. \\
6. & Kebutuhan afeksi yang tidak terpenuhi. \\
\hline
\end{tabular}

Presenting Problems :

1. Partisipan terlibat dalam tindakan kriminal dengan pasal berlapis

2. Gangguan kepribadian antisosial yang dimiliki partisipan.

\section{Precipitating Factors:}

1. Adanya seseorang yang me-rendahkan harga diri, seperti me-maki-maki atau memarahi partisipan.

2. Ketika kebutuhan financial yang kurang / tidak terpenuhi.

\section{Maintaining Factors :}

1. Berkembangnya kemampuan belajar dari sesama napi untuk melakukan hal-hal negatif untuk mendapatkan keuntungan bagi dirinya sendiri.

2. Belum ada sosok pemenuhan kebutuhan afeksi yang lebih tinggi otoritanya dibandingkan subjek.

3. Kecanduan obat-obatan terlarang, yaitu gania.

\section{$\overbrace{\text { Predictive Factors : }}$ \\ 1. Adanya minat untuk memperbaiki kehidupannya, khususnya terkait dengan perekonomian. \\ 2. Fungsi kognitif yang masih cukup baik.}

Gambar 1. Formulasi Kasus Partisipan berdasarkan DSM-V (2013)

\section{Simpulan}

Berdasarkan hasil dan pembahasan yang telah dipaparkan sebelumnya, dapat disimpulkan bahwa gangguan kepribadian antisosial yang dialami seseorang tidak langsung terbentuk dengan sendirinya. Individu dengan gangguan kepribadian antisosial sejak kecil telah menunjukkan adanya perilaku yang menyimpang dan berkembang ketika mereka remaja hingga dewasa. Faktor penyebab yang berperan dalam pembentukan gangguan kepribadian antisosial diantaranya faktor keluarga yang menerapkan adanya inkonsisten dalam pengasuhan.

Orang tua yang menerapkan pengasuhan yang bersifat memberikan hukuman baik secara fisik dan verbal akan berdampak pada cara individu dalam penyelesaian masalah. Individu akan mencontoh dan beranggapan bahwa salah satu cara untuk menyelesaikan masalah adalah dengan menggunakan kekerasan. Hal ini merupakan salah satu karakteristik gangguan 
kepribadian antisosial yang menunjukkan adanya gaya hidup yang bersifat impulsif dan kurang bertanggung jawab.

Faktor eksternal lainnya yang berperan membentuk kepribadian antisosial adalah kesalahan dalam pemilihan peergroup yang diikuti hingga adanya status perekonomian yang menengah ke bawah. Selain itu, kepribadian antisosial erat kaitannya dengan perilaku conduct yang dilakukan individu semasa masa remaja yang cenderung menetap hingga individu dewasa. Semakin muda usia onset perilaku bermasalah yang dimunculkan oleh individu, maka akan berpotensi pada keparahan dari tingkat kepribadian antisosial yang dimiliki seseorang.

\section{Saran}

Keterbatasan dalam penelitian yang telah dilakukan adalah jumlah partisipan yang terbatas, sehingga kurang dapat untuk menggambarkan secara menyeluruh dan kurang memberikan gambaran perbedaan antar individu dengan gangguan kepribadian antisosial dengan yang serupa. Oleh karena itu, saran yang dapat diajukan peneliti untuk penelitian dengan tema serupa selanjutnya adalah melakukan dengan jumlah partisipan yang lebih dari satu. Selain itu, penelitian ini juga kurang memberikan gambaran faktor penyebab dari segi biologis, sehingga kurang dapat memberikan kesimpulan terkait adanya faktor bawaan yang membentuk gangguan kepribadian tersebut.

\section{Ucapan Terima Kasih}

Ucapan terima kasih berkat berlangsungnya penelitian ini adalah yang pertama kepada dosen pembimbing peneliti yang telah meluangkan waktu, tenaga, dan bersedia untuk berbagi ilmunya dengan peneliti. Selain itu, terima kasih diucapkan kepada pihak lapas yang telah memberikan izinnya dan membantu peneliti untuk dengan muda bertemu dengan partisipan. Selanjutnya juga peneliti ucapkan terima kasih kepada partisipan yag telah bersedia meluangkan waktunya untuk bertemu dan mengukuti proses penelitian. 
Nanda Audia Vrisaba \& Ktut Dianovinina | Dinamika Narapidana

\section{Daftar Pustaka}

Adshead, G. (2015). Parenting and personality disorder: Clinical and child protection and implication. BJPsych Advances, 21, 15-22.

APA. (2013). Diagnostic and Statitical Manual of Mental Disorder Fourth Edition (DSM-V). Washintong D.C.: American Psychiatri Publishing.

Black, D.W. (2015). The natural history of antisocial personality disorder. The Canadian Journal of Psychiatry, 60(7), 309314.

Butcher, J.N., Dahlstrom, W.G., Graham, J.R., Tellegen, Y.S., \& Kaemmer, B. (1989). Minnesota Multiphasic Personality Inventory-2, user's guide, the Minnesota report: Adult clinical system. Minneapolis, MN: National Computer Systems.

Carr, A. (2006). Family therapy: Concepts, process and practice (second ed.). England.

Dahlstrom,W.G., \& Welsh, G.S. (1960). An MMPI handbook: A guide to use in clinical practice and research. Minneapolis: University of Minnesota Press.

deFarias, M.S.J.A., Gomes, A.R.F., Calheiros, M.B., Cavalcante, H.P.A., Lessa., M.M., \& Neto, V.M.L. (2013). The Antisocial Personality Disorder and its Characteristics, Changes and Advances: A Challenge. International Journal of Collaboration Research on Internal Medicine \& Public Health. Vol.5 No.1.

Feist, J., \& Feist, G.J. (2010). Teori Kepribadian Buku 2. Jakarta: Salemba Humanika.

Fernandes, S. (2019). Prediction of a rise in antisocial personality disorder through cross-generational analysis. Prediction of an Increase in Personality Disorder.

Glen, A.L., \& Raine, A. (2011). Antisocial Personality Disorder. In J. Decety \& J. Cacioppo (Eds.) The Oxford Handbook of Social Neuroscience (pp. 885-894). New York: Oxford University Press.

Hill, J. (2003). Early identification of individual at risk for antisocial personality disorder. British Journal of Psychiatry, 182, 1114.

146 | Journal An-nafs: Vol. 4 No. 2 Desember 2019 
Nanda Audia Vrisaba \& Ktut Dianovinina | Dinamika Narapidana

Kantor, M. (2006). The Psychopaty of Everyday Life: How Antisocial Personality Disorder Affects All of Us. USA: British Library Cataloguing in Publication Data

Lahey, B.B., Loeber, R., Burke, J.D., \& Applegate, B. (2005). Predicting future antisocial personality disorder in males from a clinical assessment in childhood. Journal of Consulting \& Clinical Psychology, 73(3), 389-399.

Maramis, W. E. (1980). Ilmu Kedokteran Jiwa. Airlangga University Press: Surabaya.

NICE Clinical Guidelines. (2010). Antisocial Personality Disorder: Treatment, Management, and Prevention. Leicester (UK): British Psychological Society

Sugiyono. (1999). Statistik untuk Penelitian. Bandung: Alfabeta.

Tufts, A. (2013). Born to be an offender? Antisocial personality disorder and its implications of juvenile transfer to adult court in federal proceding. Lewis \& Clark Law Review, 17, 333-359.

Walters, G.N., \& Knight, R.A. (2010). Antisocial personality disorder with and without antecedent chilhood conduct disorder: Does it make the difference?. Journal of Personality Disorder, 24(2), 258-271.

Washburn, J.J., Romero, E.G., Welty, L.J., Abram, K.M., Teplin, L.A., McClelland, G.M., \& Paskar, L.D. (2007). Development of antisocial personality disorder in detained youths: The predictive value of mental disorder. Journal of Consulting and Clinical Psychology, 75(2), 221-231. 